\title{
Constraints on HIMU and EM by Sr and Nd isotopes re-examined
}

\author{
Takeshi Hanyu ${ }^{1 *}$ and Eizo Nakamura ${ }^{2}$ \\ ${ }^{1}$ Earthquake Research Institute, University of Tokyo, Bunkyo-ku, Tokyo 113-0032, Japan \\ ${ }^{2}$ The Pheasant Memorial Laboratory, Institute for Study of the Earth's Interior, Okayama University at Misasa, \\ Misasa, Tottori 682-0122, Japan
}

(Received November 24, 1998; Revised November 5, 1999; Accepted November 5, 1999)

\begin{abstract}
$\mathrm{Sr}$ and $\mathrm{Nd}$ isotopes together with trace elements for ocean island basalts in the Polynesian region have been analyzed in order to investigate the origin of the HIMU and EM sources. Both whole rocks and cpx phenocrysts were analyzed for isotopic composition. Cpx samples from HIMU islands show quite uniform ${ }^{87} \mathrm{Sr} /{ }^{86} \mathrm{Sr} \mathrm{ratios}$ $(\sim 0.70274)$, while leached and unleached whole rock samples show variable and higher ${ }^{87} \mathrm{Sr} /{ }^{86} \mathrm{Sr}$ than those of cpx samples. These results suggest that even leached whole rock samples have been affected by secondary contaminations of sea water. On the other hand, cpx preserves a pristine isotopic signature with minimal secondary effects.

Using only the cpx analyses, HIMU form a vertical linear trend in the Sr-Nd isotope diagram with small variation in $\varepsilon_{\mathrm{Nd}}(+3.3 \sim+5.5)$ and constant ${ }^{87} \mathrm{Sr} /{ }^{86} \mathrm{Sr}$. This trend is explained by a mixing of the HIMU endmember and the MORB source. Since $\varepsilon_{\mathrm{Nd}}$ of the HIMU end-member is constrained to be less than +3.3 , the HIMU source should include former sediment added to oceanic crust. To explain the vertical nature of the mixing trend, the HIMU end-member should have similar $\mathrm{Rb} / \mathrm{Sr}$ to the MORB source, or much lower $\mathrm{Sr} / \mathrm{Nd}$ ratio than the MORB source, which favors a mixing model between extensively dehydrated oceanic crust and sediment as the HIMU source. The correlation between $\varepsilon_{\mathrm{Nd}}$ and trace element ratios such as $\mathrm{Pb} / \mathrm{Ta}$ also supports the model.
\end{abstract}

\section{Introduction}

Ocean island basalts (OIBs) are products of intra-plate volcanism which is one of the major igneous activities on the Earth's surface. In many areas, ocean islands have formed linear chains which are parallel to the movement of the plate. Their ages are consistent with the "hotspot hypothesis" that they are generated by stationary magma sources (hotspots) beneath the moving oceanic plates. Since the upper mantle is considered to be stirred, roots of stationary hotspots should be located in the deep mantle below the upper mantle. This idea suggests that OIBs give us information about the chemical characteristics of the deep mantle.

Previous geochemical studies of OIBs have revealed that the deep mantle is rather heterogeneous compared to the upper mantle. On the basis of $\mathrm{Sr}, \mathrm{Nd}$ and $\mathrm{Pb}$ isotope studies, at least four end-member components have been proposed; DM, EM1, EM2 and HIMU (e.g., Zindler and Hart, 1986). The end member DM (depleted mantle) corresponds to a component of the upper mantle. The EM end-members (enriched mantle) require high and low time-integrated $\mathrm{Rb} / \mathrm{Sr}$ and $\mathrm{Sm} / \mathrm{Nd}$ ratios, respectively. Such characteristics are similar to those presently observed in sediments and rocks from the continental crust (Zindler

* Present address: Department of Earth Sciences, Vrije Universiteit, 1081 HV Amsterdam, The Netherlands.

Copy right $\odot$ The Society of Geomagnetism and Earth, Planetary and Space Sciences (SGEPSS); The Seismological Society of Japan; The Volcanological Society of Japan; The Geodetic Society of Japan; The Japanese Society for Planetary Sciences. and Hart, 1986; Ben Othman et al., 1989). Accordingly, models proposed for the origin of EM components include sediment recycling (e.g., Weaver, 1991; Chauvel et al., 1992) and delamination of the subcontinental lithosphere into the deep mantle (e.g., McKenzie and O'Nions, 1983).

On the other hand, the origin of the HIMU (high- $\mu$ ) endmember is still debatable, because no source material has been found which has isotopic characteristics similar to HIMU. Most previous studies have discussed processes which might produce the high $\mathrm{Pb}$ isotope ratios or high time-integrated $(\mathrm{U}+\mathrm{Th}) / \mathrm{Pb}$ of HIMU. These processes include reaction with core (Vidal and Dosso, 1978; Allègre et al., 1980), recycled oceanic crust and sediment (Hofmann and White, 1982; Weaver, 1991; Chauvel et al., 1992; Hofmann, 1997; Kogiso et al., 1997) and metasomatic enrichment in the mantle or subcontinental lithosphere (McKenzie and O'Nions, 1983; Vollmer, 1983; Nakamura and Tatsumoto, 1988; Sun and McDonough, 1989; Halliday et al., 1995). Recent studies applying isotopes of oxygen (Eiler et al., 1997), osmium (Hauri and Hart, 1993; Reisberg et al., 1993; Roy-Barman and Allègre, 1995) and helium (Graham et al., 1992; Hanyu and Kaneoka, 1997) provide more constraints on the origin of HIMU. However, the fact that HIMU plots away from the mantle array in the $\mathrm{Sr}-\mathrm{Nd}$ isotope diagram has not yet been well examined.

The aim of this study is to further constrain the $\mathrm{Sr}$ and $\mathrm{Nd}$ isotopic composition as well as the trace element (including REE) characteristics of HIMU and EM in the Polynesian region by precise measurement of both cpx 
phenocryst and whole rock samples. The data are then used to constrain the origin of HIMU.

\section{Geological and Geochemical Background}

There are five island chains in the Polynesian region; Marquesas, Tuamotu, Gambier, Society and Cook-Austral Archipelagoes. The dense distribution of hotspot volcanism in the Polynesian region may be related to the so-called "Superswell" which is characterized by elevated topography (McNutt and Judge, 1990). It is accompanied by a negative geoid anomaly and slow seismic velocity under the region (McNutt and Judge, 1990). The seismic velocity anomaly in the lower mantle can be linked to the upwelling of mantle material (Dziewonski, 1984; Fukao, 1992).

The Cook-Austral Archipelago is one of the places where HIMU-OIBs are observed at Mangaia, Rurutu, Tubuai and Rimatara Islands (Palacz and Saunders, 1986; Nakamura and Tatsumoto, 1988; Chauvel et al., 1992; Kogiso et al., 1997). This archipelago, however, includes other islands whose rocks are characterized as EM1 (Palacz and Saunders, 1986; Nakamura and Tatsumoto, 1988;
Chauvel et al., 1992; Hémond et al., 1994). Geochronological data indicate that the ages of HIMU islands and part of EM1 islands (e.g., Raivavae and Rapa) are consistent with the "hotspot hypothesis" indicating that they are products of a fixed hotspot at the MacDonald Seamount (Duncan and McDougall, 1976; Turner and Jarrard, 1982). However, other EM1 islands (e.g., Aitutaki, Rarotonga, Atiu, Mititaro, Mauke) have much younger ages than predicted by the "hotspot hypothesis" and show no correlation between age and location (Turner and Jarrard, 1982). Several hotspots located parallel to the direction of movement of the Pacific Plate are required to explain the ages and isotopic variation of these islands (e.g., Chauvel et al., 1997). McNutt et al. (1997) have found quite old islands and seamounts (23-40 Ma) around the MacDonald Seamount and they suggest that these islands and seamounts had been produced by diverse upwelling of mantle materials, rather than narrow fixed hotspots.

Rock samples used in this study were obtained from four islands in the Cook-Austral Archipelago. Ten HIMU basalts were obtained from Mangaia, Rurutu and Tubuai (a) TU01-01

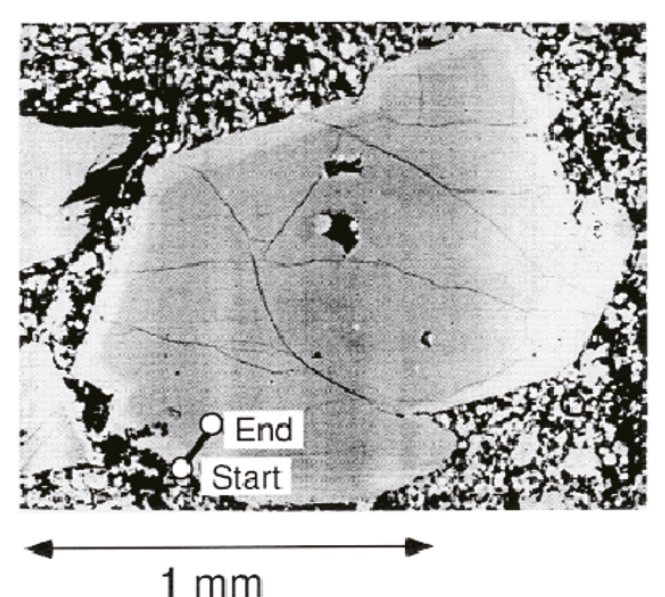

(b) RTG-C10

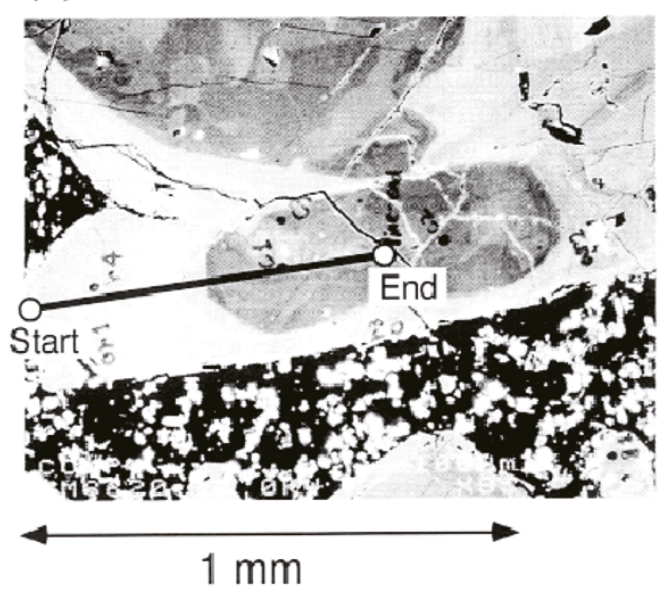

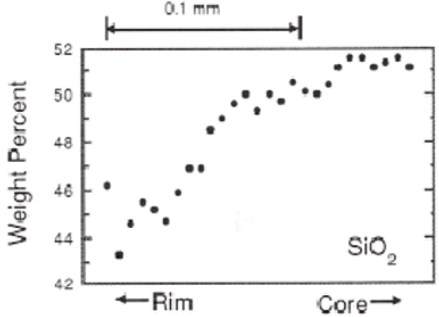
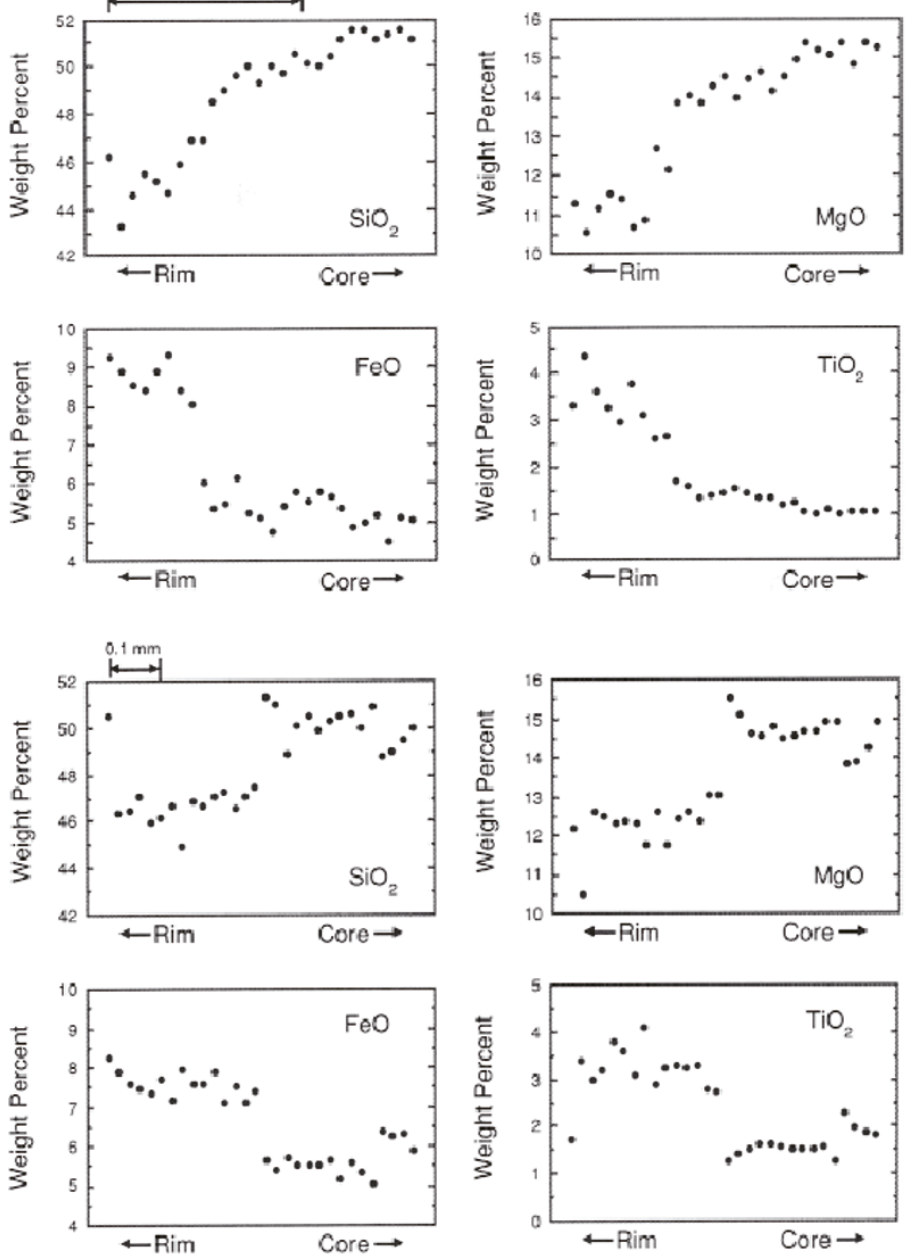

Fig. 1. Photographs and major element profiles of cpx from samples TU01-01 (a) and RTG-C10 (b). The analyses for major elements were performed by EPMA along lines starting from the rim ("Start") to the core ("End"). 
Islands. Ages of Mangaia and Tubuai Islands are around $18 \mathrm{Ma}$ and $10 \mathrm{Ma}$, respectively. Binary volcanic activity is observed in Rurutu Island: the ancient series lavas (around $12 \mathrm{Ma}$ ) are classified as typical HIMU while recent series lavas (1-2 Ma) show lower $\mathrm{Pb}$ isotope ratios (Barsczus et al., 1994; Chauvel et al., 1997). The ancient series lavas were selected for the analyses. For comparison with HIMU basalts, four samples of EM1 basalts were obtained from Rarotonga Island. Most of the samples are olivine and cpx phyric alkali basalts. Least altered rocks were selected for the analyses. Noble gas isotope analyses were performed for some of these samples (Hanyu and Kaneoka, 1997; Hanyu et al., 1999).

\section{Analytical Methods}

Rock samples were chopped by a hammer or cut by a diamond saw, and then crushed by a jaw crusher. Any cutting sections on rock pieces cut by a diamond saw were removed by hand-picking to avoid contamination. The chips were subsequently washed by distilled water and dried, and an aliquot ground into powder in a swing mill made of alumina ceramics. To obtain cpx samples, the remaining chips were further crushed in an iron mortar into the mesh size of \#60-\#80. Cpx was separated using a magnetic separator.

Because cpx phenocrysts show normal zoning (Fig. 1), rims and cores were separated to estimate the difference in elemental and isotopic compositions between them for two selected samples (RTG-C10 and TU01-01). Cpx with mesh size of \#100-\#200 were used for this purpose. First, pure cpx, including both rim and core parts was separated magnetically. Then, the cpx was leached by hot $2 \mathrm{~N}-\mathrm{HCl}$ and the rims and cores further separated magnetically by taking advantage of the difference in their Fe content (Fig. 1). As the colors of the rims and cores were different due to different contents of $\mathrm{Ti}$ and $\mathrm{Cr}$, purity could be roughly checked using a binocular microscope. Further checking was performed by the electron probe micro analyzer (EPMA) for randomly picked grains. The rimrich part and core-rich part were estimated to include more than $80 \%$ of rim and core, respectively.

Trace elements were analyzed by inductively coupled plasma-mass spectrometry (ICP-MS) at the Pheasant Memorial Laboratory (PML) of the Institute for Study of the Earth's Interior (ISEI), Okayama University at Misasa. The chemical treatments and mass spectrometric procedures follow Makishima and Nakamura (1997) and Makishima et al. (1999). Analytical reproducibility of the measurements for each element in basaltic samples, was better than $5 \%(2 \sigma)$, and typically $2 \%$. Some samples were selected for duplicate analyses.

$\mathrm{Sr}$ and $\mathrm{Nd}$ isotopic analyses were carried out for both cpx and whole rock samples. Before decomposition, cpx and whole rock samples were leached by $6 \mathrm{~N}-\mathrm{HCl}$ at $80^{\circ} \mathrm{C}$ for 12 hours. Three whole rock samples were chosen to evaluate the leaching effect by comparing results from leached and unleached runs. Isotopic measurements were performed by a thermal ionization mass spectrometer, Finnigan MAT 262 equipped with multi-collector system, at PML in Misasa following the procedures reported in
Yoshikawa and Nakamura (1993) and Shibata and Nakamura (1997). Sr isotopes were normalized to ${ }^{86} \mathrm{Sr} /$ ${ }^{88} \mathrm{Sr}=0.1194$ and measured value of ${ }^{87} \mathrm{Sr} /{ }^{86} \mathrm{Sr}$ was corrected so that ${ }^{87} \mathrm{Sr} /{ }^{86} \mathrm{Sr}$ of NIST981 (measured value was 0.710112 ) was adjusted to 0.710238 . $\mathrm{Nd}$ isotopes were normalized to ${ }^{146} \mathrm{Nd} /{ }^{144} \mathrm{Nd}=0.7219$ and measured value of ${ }^{143} \mathrm{Nd} /{ }^{144} \mathrm{Nd}$ was corrected so that ${ }^{143} \mathrm{Nd} /{ }^{144} \mathrm{Nd}$ of La Jolla isotopic standard (measured value was 0.511821 ) was adjusted to 0.511838 . Procedural total blanks of $\mathrm{Sr}$ and $\mathrm{Nd}$ were $30 \mathrm{pg}$ and $70 \mathrm{pg}$, respectively.

\section{Results \\ 4.1 Cpx zoning}

All cpx samples analyzed in the present study show normal zoning. Two cpx samples, RTG-C10 and TU0101 , were selected for checking the effects of zoning on elemental and isotopic compositions (this experiment is termed "rim-core test" hereafter). The zoning patterns were investigated by EPMA.

Most cpx have zoning patterns typified by sample TU0101 (Fig. 1). They have continuous zoning which abut on thin rims $(<100 \mu \mathrm{m})$. Both rim and core are Ti-augite, but the major element composition of rim is different from that of core. The difference in the Fe content between rim and core enables the separation of rim-rich parts and corerich parts of cpx by magnetic separation for the rim-core test.

Only cpx of sample RTG-C10 has a zoning pattern different from that of the other samples. It is discontinuous and terminated by a thicker rim (Fig. 1). Rim and core are classified as $\mathrm{Ti}$-augite and $\mathrm{Cr}$-diopside, respectively.

\section{2 $\mathrm{Sr}$ and $\mathrm{Nd}$ isotopes}

Results of the $\mathrm{Sr}$ and $\mathrm{Nd}$ isotope analyses are listed in Table $1 .{ }^{87} \mathrm{Sr} /{ }^{86} \mathrm{Sr}$ and ${ }^{143} \mathrm{Nd} /{ }^{144} \mathrm{Nd}\left(\varepsilon_{\mathrm{Nd}}\right)$ ratios of HIMU samples (Mangaia, Rurutu and Tubuai) have similar values to those previously reported (Palacz and Saunders, 1986; Nakamura and Tatsumoto, 1988; Chauvel et al., 1992; Chauvel et al., 1997). They all plot below the so-called mantle array (Fig. 2).

The rim-core test reveals that within analytical error, both RTG-C10 and TU01-01 show indistinguishable isotope ratios between the rim-rich and the core-rich fraction of cpx (Table 1, Fig. 2). This excludes the possibility of contamination of the parent magma by exotic material during cpx formation.

When leached and unleached whole rock samples are compared, the unleached ones always show higher ${ }^{87} \mathrm{Sr} /$ ${ }^{86} \mathrm{Sr}$ than the leached ones (Fig. 3). This suggests that the unleached whole rock samples have been affected by secondary contamination, probably in the form of adhering seawater with high ${ }^{87} \mathrm{Sr} /{ }^{86} \mathrm{Sr}$ ratio $(\sim 0.709)$, which could be more or less removed by acid leaching. Such a problem has previously been reported for $\mathrm{Pb}$ isotope ratios (McDonough and Chauvel, 1991). However, leached whole rock samples always show higher ${ }^{87} \mathrm{Sr} /{ }^{86} \mathrm{Sr}$ than cpx samples (Fig. 3). One of the possible explanations for this is radiogenic ingrowth in the whole rock samples because $\mathrm{Rb} / \mathrm{Sr}$ ratios of the whole rocks are higher than those of cpx samples. Ingrowth of ${ }^{87} \mathrm{Sr} /{ }^{86} \mathrm{Sr}$ in the whole rocks and cpx after eruption is estimated in Fig. 4. Radiogenic 
Table 1. Errors $(2 \sigma)$ correspond to the last two digits of values. $\varepsilon_{\mathrm{v}}$ corresponds to deviations in parts per $10^{4}$ from the present day bulk Earth values; ${ }^{143} \mathrm{Nd} /{ }^{144} \mathrm{Nd}=0.512638$.

\section{(a) Cpx samples.}

\begin{tabular}{|c|c|c|c|c|}
\hline Sample & & ${ }^{87} \mathrm{Sr} / 86 \mathrm{Sr}$ & ${ }^{143} \mathrm{Nd} /{ }^{144} \mathrm{Nd}$ & $\varepsilon_{\mathrm{Nd}}$ \\
\hline \multicolumn{5}{|l|}{ Rarotonga } \\
\hline RTG-C4 & & $0.704067 \pm 10$ & $0.512696 \pm 10$ & $1.1 \pm 0.2$ \\
\hline RTG-C5 & & $0.704403 \pm 8$ & $0.512692 \pm 12$ & $1.1 \pm 0.2$ \\
\hline RTG-C8 & & $0.704128 \pm 9$ & $0.512717 \pm 13$ & $1.5 \pm 0.3$ \\
\hline \multirow[t]{2}{*}{ RTG-C10 } & core & $0.704034 \pm 10$ & $0.512716 \pm 15$ & $1.5 \pm 0.3$ \\
\hline & rim & $0.704061 \pm 10$ & $0.512729 \pm 11$ & $1.8 \pm 0.2$ \\
\hline \multicolumn{5}{|l|}{ Mangaia } \\
\hline MGA-C8 & & $0.702733 \pm 8$ & $0.512863 \pm 10$ & $4.4 \pm 0.2$ \\
\hline MGA-C12 & & $0.702731 \pm 9$ & $0.512845 \pm 16$ & $4.0 \pm 0.3$ \\
\hline MGA-C23 & & $0.702746 \pm 12$ & $0.512868 \pm 12$ & $4.5 \pm 0.2$ \\
\hline MGA-C29 & & $0.702742 \pm 8$ & 0.51280 & $3.3 \pm 0.3$ \\
\hline \multicolumn{5}{|l|}{ Tubuai } \\
\hline \multirow[t]{2}{*}{ TU01-01 } & core & $0.702731 \pm 9$ & $0.512898 \pm 12$ & $5.1 \pm 0.2$ \\
\hline & & $0.702713 \pm 9$ & $0.512920 \pm 11$ & $5.5 \pm 0.2$ \\
\hline TU09-01 & & $0.702766 \pm 10$ & $0.512895 \pm 12$ & $5.0 \pm 0.2$ \\
\hline TU12-01 & & $0.702734 \pm 10$ & $0.512869 \pm 12$ & $4.5 \pm 0.2$ \\
\hline \multicolumn{5}{|l|}{ Rurutu } \\
\hline RU01-01 & & $0.702751 \pm 9$ & $0.512878 \pm 12$ & $4.7 \pm 0.2$ \\
\hline RU02-01 & & $0.702720 \pm 9$ & $0.512846 \pm 14$ & $4.1 \pm 0.3$ \\
\hline RU09-01 & & $0.702725 \pm 9$ & $0.512881 \pm 15$ & $4.7 \pm 0.3$ \\
\hline
\end{tabular}

\section{(b) Leached whole rock samples.}

\begin{tabular}{lccc}
\hline Sample & $87 \mathrm{Sr} / 86 \mathrm{Sr}$ & $143 \mathrm{Nd} / 144 \mathrm{Nd}$ & $\boldsymbol{E}_{\mathrm{Nd}}$ \\
\hline Rarotonga & & & \\
RTG-C4 & $0.704281 \pm 9$ & $0.512715 \pm 7$ & $1.5 \pm 0.1$ \\
RTG-C5 & $0.704424 \pm 10$ & $0.512663 \pm 10$ & $0.5 \pm 0.2$ \\
RTG-C8 & $0.704181 \pm 9$ & $0.512690 \pm 18$ & $1.0 \pm 0.4$ \\
RTG-C10 & $0.704092 \pm 10$ & $0.512705 \pm 13$ & $1.3 \pm 0.3$ \\
Mangaia & & & \\
MGA-C8 & $0.702807 \pm 10$ & $0.512837 \pm 8$ & $3.9 \pm 0.2$ \\
MGA-C12 & $0.702776 \pm 11$ & $0.512865 \pm 9$ & $4.4 \pm 0.2$ \\
MGA-C23 & $0.702809 \pm 9$ & $0.512853 \pm 5$ & $4.2 \pm 0.1$ \\
MGA-C29 & $0.702797 \pm 12$ & $0.512852 \pm 6$ & $4.2 \pm 0.1$ \\
Tubuai & & & \\
TU01-01 & $0.702779 \pm 10$ & $0.512886 \pm 12$ & $4.8 \pm 0.2$ \\
TU09-01 & $0.702802 \pm 9$ & $0.512891 \pm 9$ & $4.9 \pm 0.2$ \\
TU12-01 & $0.702802 \pm 10$ & $0.512903 \pm 5$ & $5.2 \pm 0.1$ \\
Rurutu & & & \\
RU01-01 & $0.702765 \pm 8$ & $0.512872 \pm 7$ & $4.6 \pm 0.1$ \\
RU02-01 & $0.702794 \pm 11$ & $0.512850 \pm 11$ & $4.1 \pm 0.2$ \\
RU09-01 & $0.702805 \pm 10$ & $0.512894 \pm 5$ & $5.0 \pm 0.1$ \\
\hline
\end{tabular}

\section{(c) Unleached whole rock samples.}

\begin{tabular}{lccc}
\hline Sample & $87 \mathrm{Sr} / 86 \mathrm{Sr}$ & $143 \mathrm{Nd} /{ }^{144} \mathrm{Nd}$ & $\varepsilon_{\mathrm{Nd}}$ \\
\hline $\begin{array}{c}\text { Mangaia } \\
\text { MGA-C12 }\end{array}$ & $0.702883 \pm 9$ & $0.512860 \pm 7$ & $4.3 \pm 0.1$ \\
$\begin{array}{c}\text { Tubuai } \\
\text { TU01-01 } \\
\begin{array}{c}\text { Rurutu } \\
\text { RU01-01 }\end{array}\end{array}$ & $0.702832 \pm 10$ & $0.512908 \pm 5$ & $5.3 \pm 0.1$ \\
& $0.702873 \pm 13$ & $0.512891 \pm 5$ & $4.9 \pm 0.1$ \\
\hline
\end{tabular}

ingrowth may partly contribute to observed $\mathrm{Sr}$ isotopic difference between them, but the difference still remains exceeding analytical error even if the age correction is practiced. This suggests that even leached whole rock samples inherit secondary contamination which cannot be removed by the acid leaching. The fact that cpx appears to be free from subsolidus contamination suggests that cpx retains more original isotopic information and is therefore more suitable for precise measurement of isotopes, especially, when dealing with oceanic island samples.

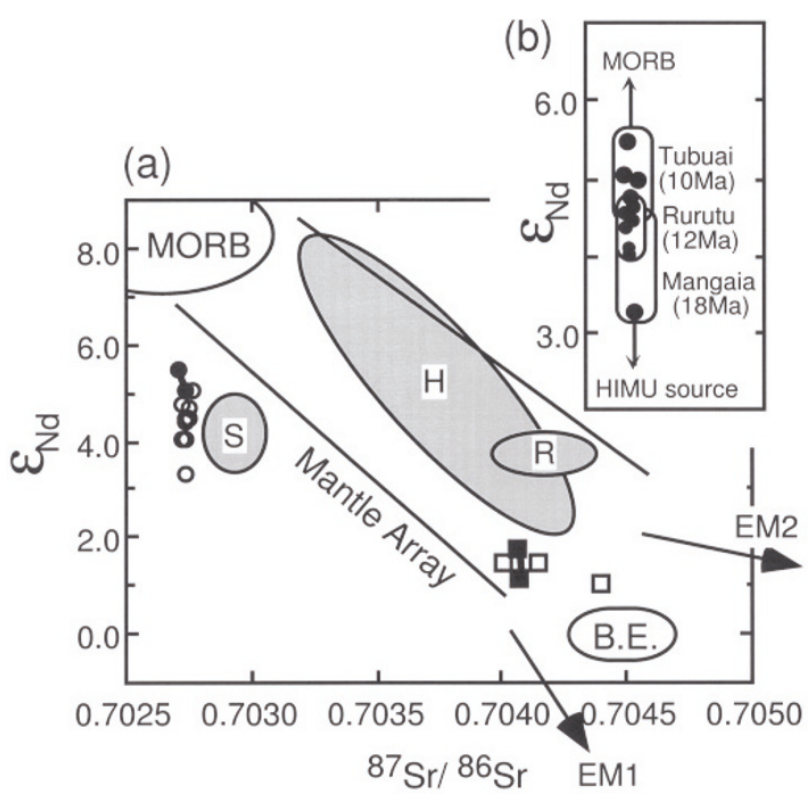

Fig. 2. (a) ${ }^{87} \mathrm{Sr} /{ }^{86} \mathrm{Sr}-\varepsilon_{\mathrm{Nd}}$ diagram for cpx data of HIMU (circle) and Rarotonga (square) samples. The solid symbols connected by a line are rim and core pairs of cpx. Isotopic ranges of Hawaii $(\mathrm{H})$, Reunion (R) and St. Helena (S) are indicated by shaded areas (e.g., Zindler and Hart, 1986). (b) Correlation between $\varepsilon_{\mathrm{Nd}}$ and the ages of the HIMU islands.

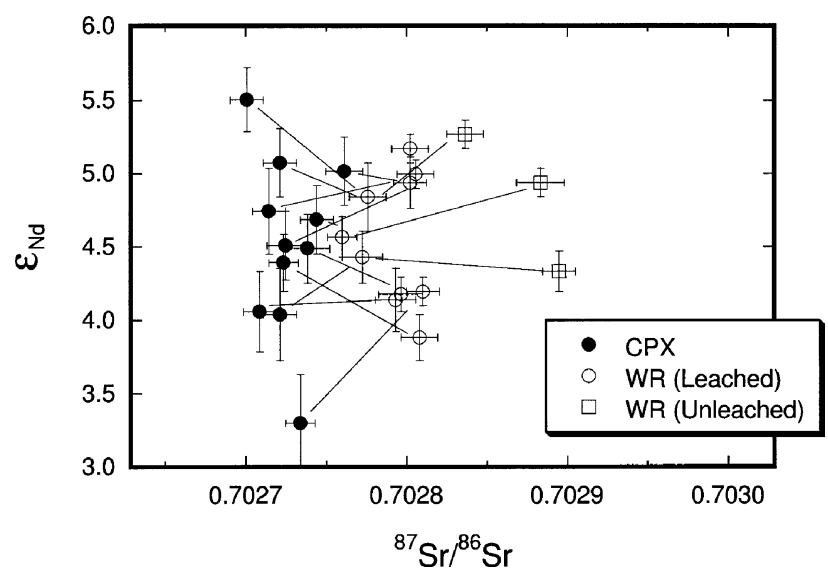

Fig. 3. Comparison of ${ }^{87} \mathrm{Sr} /{ }^{86} \mathrm{Sr}$ and $\varepsilon_{\mathrm{Nd}}$ of cpx, leached and unleached whole rock (WR) samples. Samples from the same rocks are connected by lines. Error bars are $\pm 2 \sigma$.

\subsection{Trace elements}

Trace element data are summarized in Table 2. The primitive mantle normalized trace element patterns of whole rock samples are shown in Fig. 5. A highly fractionated pattern of incompatible elements is usually found in OIBs, indicating that magmas were formed with garnet-bearing residues. $\mathrm{Nb}$ and Ta enrichment relative to La previously reported in HIMU-OIBs (Weaver, 1991) is also found in our data, albeit not as conspicuously. The other high field strength elements (HFSE), Zr and Hf, are depleted, probably due to residual garnet during melting because $\mathrm{Zr}$ and $\mathrm{Hf}$ are slightly less incompatible in garnet than large ion lithophile elements (LILE) with similar 


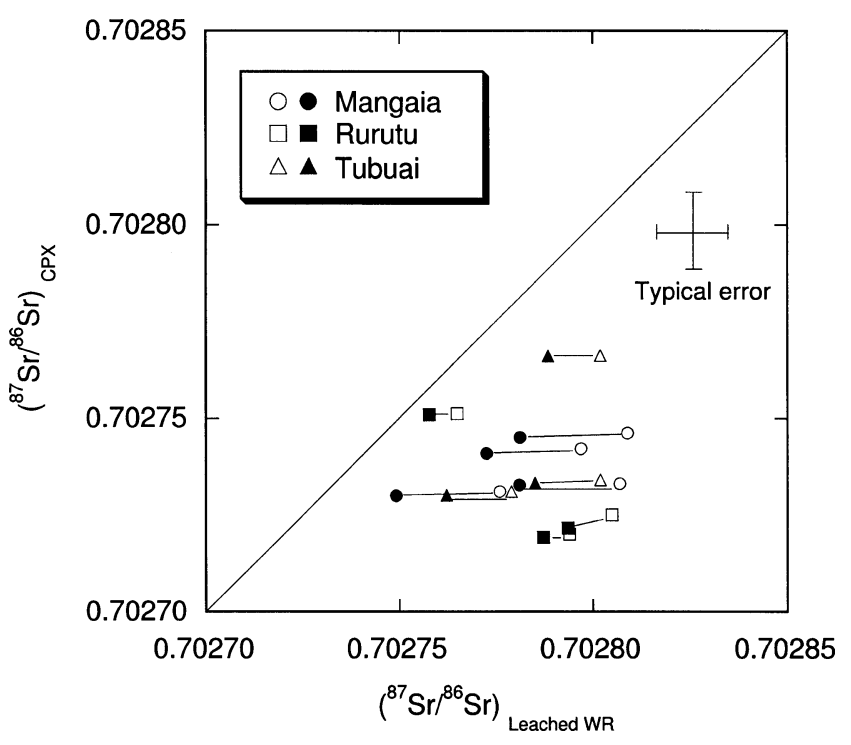

Fig. 4. Age correction of ${ }^{87} \mathrm{Sr} /{ }^{86} \mathrm{Sr}$ of the whole rock and cpx samples. Open and solid symbols indicate raw and corrected ${ }^{87} \mathrm{Sr} /{ }^{86} \mathrm{Sr}$, respectively. Shift of ${ }^{87} \mathrm{Sr} /{ }^{86} \mathrm{Sr}$ is calculated by using $\mathrm{Rb} / \mathrm{Sr}$ ratio of each sample and assuming ages as $18 \mathrm{Ma}, 12 \mathrm{Ma}$ and $10 \mathrm{Ma}$ for Mangaia, Rurutu and Tubuai, respectively. Typical error bars correspond to $\pm 2 \sigma$.

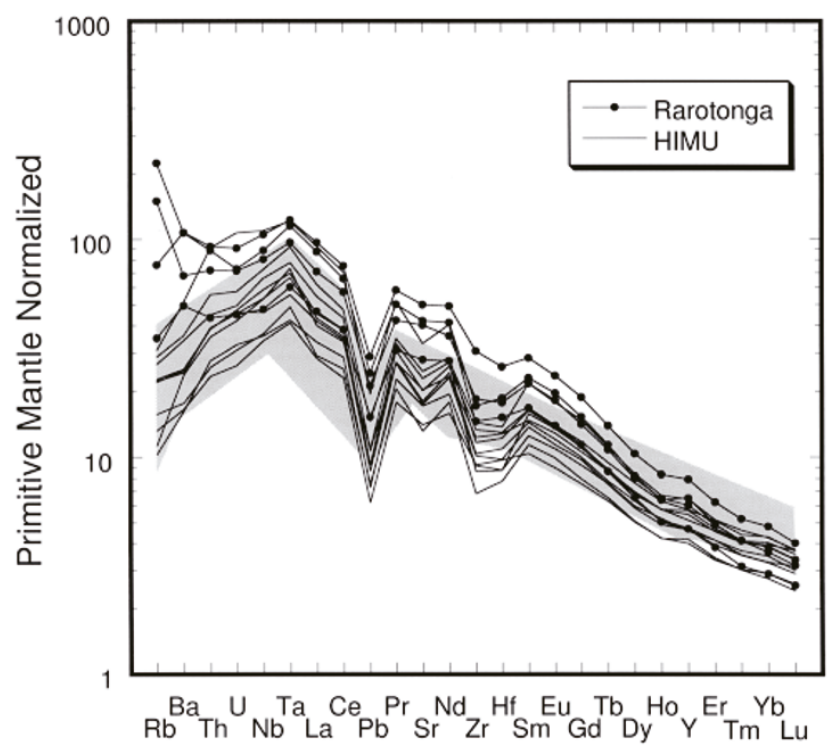

Fig. 5. Primitive mantle normalized abundance patterns of trace elements in the whole rock samples. Normalizing values are taken Hofmann (1988). Shadows demonstrates HIMU rocks from Rurutu (old series) after Chauvel et al. (1997).

incompatibility to other minerals (e.g., Nd and Sm; Green, 1994). The trace elemental pattern of rocks from the Rarotonga Island is almost akin to patterns of rocks from the HIMU islands. For highly incompatible elements $(\mathrm{Cs} \sim \mathrm{Nb})$, however, it is noteworthy that the more incompatible elements are less enriched in HIMU-OIBs, while Rarotonga OIBs have relatively flat patterns. Furthermore, $\mathrm{Pb}$ negative anomalies are characteristically developed in HIMU samples and these are stronger than those of the Rarotonga samples (Fig. 5).
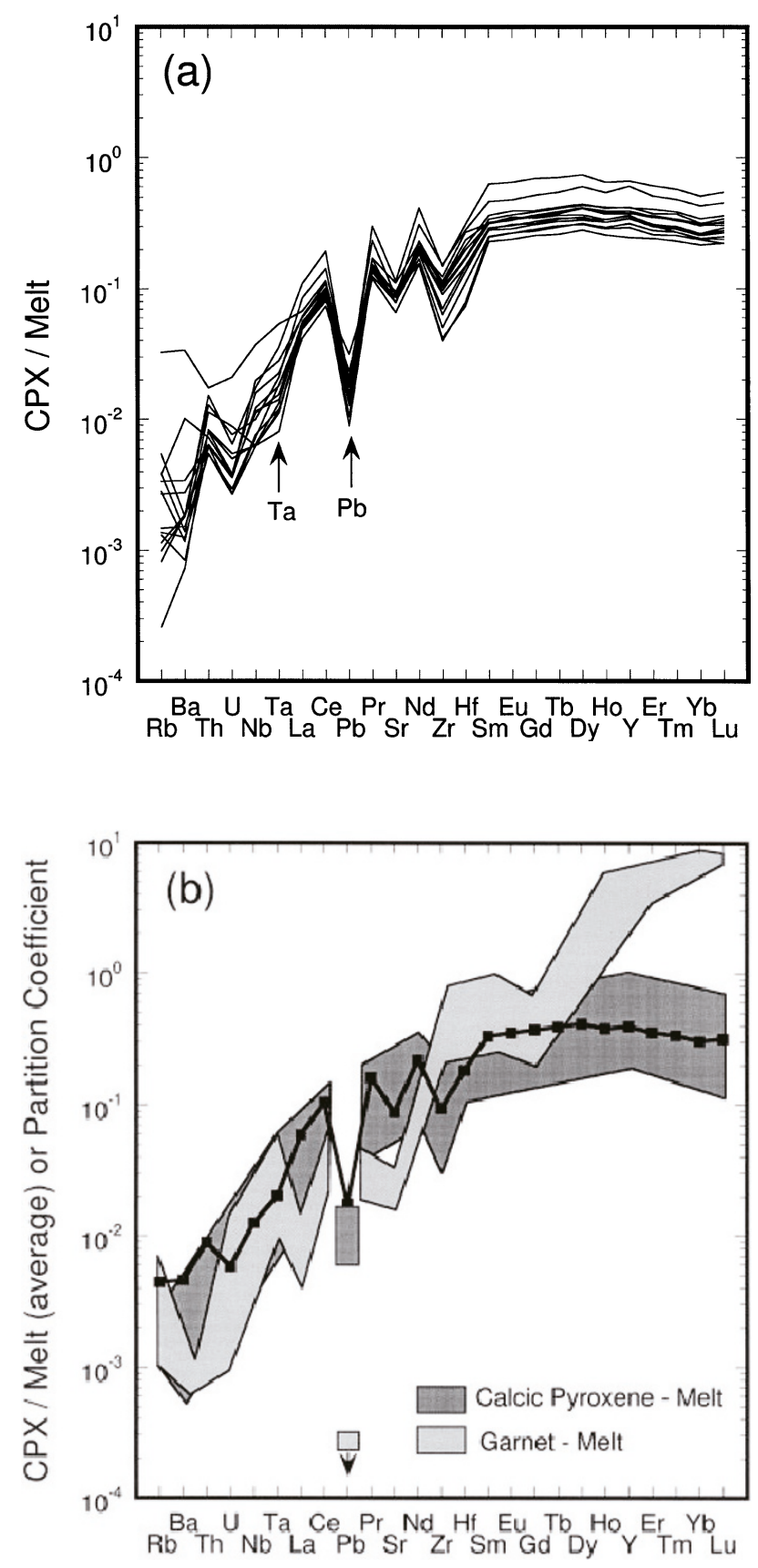

Fig. 6. (a) Concentration ratios of $\mathrm{cpx}$ and melt for HIMU and Rarotonga samples. (b) Average of them is shown by a solid line. Generalized trends for partition coefficients of calcic pyroxene/melt and garnet/melt are from Green (1994). Note that experimentally determined partition coefficient for $\mathrm{Pb}$ is usually lower than that determined by interpolation between the partition coefficients of $\mathrm{Ce}$ and $\mathrm{Sr}$ for both calcic pyroxene/melt and garnet/melt (Green, 1994).

Figure 6 shows the ratios of element concentrations in cpx over those in melt. The averages of these ratios define a pattern similar to the pattern of partition coefficients between cpx and melt (Green, 1994), indicating that cpx is nearly in equilibrium with the coexisting melt with respect to trace elements.

The result of the rim-core test is shown in Fig. 7. All REEs in the rim-rich fractions show a nearly 2-fold enrichment of those in the core-rich fractions for both cpx samples (RTG-C10 and TU01-01). This difference in 
Table 2. All values are given in ppm.

(a) Trace element concentrations of whole rock samples.

\begin{tabular}{|c|c|c|c|c|c|c|c|c|c|c|c|c|c|c|}
\hline Sample & RTG-C4 & RTG-C5 & RTG-C8 & RTG-C10 & MGA-C & MGA-C12 & MGA-C23 & MGA-C29 & TU01-01 & TU09-01 & TU12-01 & RU01-01 & RU02-01 & RU09-01 \\
\hline $\begin{array}{l}\mathrm{La} \\
\mathrm{Ce} \\
\mathrm{Pr} \\
\mathrm{Nd} \\
\mathrm{Sm} \\
\mathrm{Eu} \\
\mathrm{Gd} \\
\mathrm{Tb} \\
\mathrm{Dy} \\
\mathrm{Ho} \\
\mathrm{Er} \\
\mathrm{Tm} \\
\mathrm{Yb} \\
\mathrm{Lu}\end{array}$ & $\begin{array}{r}32.0 \\
68.1 \\
8.5 \\
37.2 \\
7.5 \\
2.4 \\
6.8 \\
0.9 \\
4.8 \\
0.8 \\
1.8 \\
0.2 \\
1.4 \\
0.2\end{array}$ & $\begin{array}{r}60.2 \\
117 \\
13.9 \\
56.0 \\
10.3 \\
3.3 \\
9.1 \\
1.2 \\
6.1 \\
1.0 \\
2.4 \\
0.3 \\
1.8 \\
0.2\end{array}$ & $\begin{array}{r}66.3 \\
134 \\
16.1 \\
66.8 \\
12.7 \\
4.0 \\
11.2 \\
1.5 \\
7.7 \\
1.4 \\
3.0 \\
0.4 \\
2.4 \\
0.3\end{array}$ & $\begin{array}{r}48.7 \\
101 \\
11.7 \\
48.8 \\
9.7 \\
3.1 \\
8.4 \\
1.2 \\
5.9 \\
1.1 \\
2.3 \\
0.3 \\
1.9 \\
0.2\end{array}$ & $\begin{array}{r}20.1 \\
44.9 \\
5.7 \\
24.3 \\
5.1 \\
1.7 \\
4.8 \\
0.7 \\
3.7 \\
0.7 \\
1.6 \\
0.2 \\
1.4 \\
0.2\end{array}$ & $\begin{array}{r}29.8 \\
63.2 \\
7.6 \\
32.9 \\
6.4 \\
2.0 \\
6.0 \\
0.8 \\
4.6 \\
0.8 \\
2.0 \\
0.3 \\
1.6 \\
0.2\end{array}$ & $\begin{array}{r}28.8 \\
61.4 \\
7.4 \\
31.2 \\
6.1 \\
1.9 \\
5.8 \\
0.8 \\
4.3 \\
0.8 \\
1.9 \\
0.3 \\
1.6 \\
0.2\end{array}$ & $\begin{array}{r}31.2 \\
67.8 \\
8.5 \\
35.4 \\
7.3 \\
2.4 \\
7.0 \\
1.0 \\
5.6 \\
1.0 \\
2.5 \\
0.3 \\
2.1 \\
0.3\end{array}$ & $\begin{array}{r}42.6 \\
84.3 \\
9.7 \\
38.8 \\
7.3 \\
2.3 \\
6.6 \\
0.9 \\
5.0 \\
0.9 \\
2.3 \\
0.3 \\
2.0 \\
0.3\end{array}$ & $\begin{array}{r}63.8 \\
126 \\
14.2 \\
54.7 \\
9.7 \\
3.0 \\
8.8 \\
1.2 \\
6.2 \\
1.1 \\
2.5 \\
0.3 \\
2.1 \\
0.3\end{array}$ & $\begin{array}{r}37.5 \\
77.0 \\
9.1 \\
36.8 \\
7.1 \\
2.3 \\
6.7 \\
1.0 \\
5.1 \\
0.9 \\
2.2 \\
0.3 \\
1.9 \\
0.3\end{array}$ & $\begin{array}{r}23.1 \\
51.0 \\
6.3 \\
26.4 \\
5.6 \\
1.8 \\
5.5 \\
0.8 \\
4.4 \\
0.9 \\
2.0 \\
0.3 \\
1.7 \\
0.2\end{array}$ & $\begin{array}{r}27.5 \\
60.2 \\
7.5 \\
31.7 \\
6.6 \\
2.2 \\
6.3 \\
0.9 \\
5.1 \\
0.9 \\
2.2 \\
0.3 \\
1.9 \\
0.3\end{array}$ & $\begin{array}{r}19.5 \\
41.0 \\
4.9 \\
21.6 \\
4.6 \\
1.5 \\
4.5 \\
0.7 \\
3.7 \\
0.7 \\
1.6 \\
0.2 \\
1.4 \\
0.2\end{array}$ \\
\hline $\begin{array}{l}\mathrm{Rb} \\
\mathrm{Ba} \\
\mathrm{Th} \\
\mathrm{U} \\
\mathrm{Nb} \\
\mathrm{Ta} \\
\mathrm{Pb} \\
\mathrm{Sr} \\
\mathrm{Zr} \\
\mathrm{Hf} \\
\mathrm{Y} \\
\end{array}$ & $\begin{array}{c}22.4 \\
346 \\
3.7 \\
0.9 \\
33.9 \\
2.5 \\
2.8 \\
589 \\
164 \\
4.7 \\
21.3 \\
\end{array}$ & $\begin{array}{c}142 \\
748 \\
7.6 \\
1.5 \\
63.4 \\
4.7 \\
4.5 \\
892 \\
193 \\
5.8 \\
29.5\end{array}$ & $\begin{array}{c}48.3 \\
752 \\
7.9 \\
1.9 \\
75.0 \\
5.0 \\
5.3 \\
1054 \\
344 \\
8.0 \\
36.1 \\
\end{array}$ & $\begin{array}{c}95.3 \\
474 \\
6.1 \\
1.5 \\
57.8 \\
4.0 \\
3.9 \\
850 \\
207 \\
5.5 \\
27.4 \\
\end{array}$ & $\begin{array}{c}10.0 \\
124 \\
2.2 \\
0.7 \\
26.3 \\
2.0 \\
1.4 \\
279 \\
76.6 \\
2.4 \\
19.0 \\
\end{array}$ & $\begin{array}{c}14.1 \\
174 \\
3.3 \\
1.0 \\
38.0 \\
2.7 \\
1.7 \\
381 \\
117 \\
3.4 \\
21.5 \\
\end{array}$ & $\begin{array}{c}14.2 \\
170 \\
3.3 \\
1.0 \\
32.9 \\
2.3 \\
1.6 \\
370 \\
114 \\
3.0 \\
21.0\end{array}$ & $\begin{array}{c}14.4 \\
177 \\
3.3 \\
1.0 \\
41.8 \\
2.9 \\
1.7 \\
427 \\
150 \\
4.0 \\
26.1 \\
\end{array}$ & $\begin{array}{c}18.3 \\
253 \\
4.7 \\
1.2 \\
51.8 \\
3.8 \\
2.7 \\
524 \\
131 \\
3.8 \\
25.9\end{array}$ & $\begin{array}{c}19.7 \\
360 \\
7.8 \\
2.2 \\
78.0 \\
5.0 \\
3.6 \\
701 \\
162 \\
4.3 \\
29.2 \\
\end{array}$ & $\begin{array}{c}16.9 \\
240 \\
3.8 \\
1.0 \\
47.2 \\
3.2 \\
2.0 \\
484 \\
96.5 \\
2.7 \\
23.3 \\
\end{array}$ & $\begin{array}{c}6.6 \\
114 \\
2.4 \\
0.7 \\
25.7 \\
1.7 \\
1.3 \\
364 \\
102 \\
2.7 \\
20.7\end{array}$ & $\begin{array}{c}7.2 \\
166 \\
3.0 \\
0.9 \\
37.9 \\
3.0 \\
2.0 \\
431 \\
138 \\
4.0 \\
24.8\end{array}$ & $\begin{array}{c}8.4 \\
116 \\
2.0 \\
0.6 \\
24.3 \\
1.7 \\
1.1 \\
297 \\
103 \\
3.0 \\
18.2 \\
\end{array}$ \\
\hline
\end{tabular}

(b) Trace element concentrations of cpx samples.

\begin{tabular}{|c|c|c|c|c|c|c|c|c|c|c|c|c|c|c|c|c|}
\hline Sample & 2TG-C4 & RTG-C5 & TTG-C & $\begin{array}{c}\text { G-C10 } \\
\text { Core }\end{array}$ & $\begin{array}{l}\text { G-C10 } \\
\text { Rim }\end{array}$ & MGA-C & & & 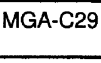 & $\begin{array}{c}\begin{array}{c}01-01 \\
\text { Core }\end{array} \\
\end{array}$ & $\begin{array}{r}\text { TU01-01 } \\
\text { Rim } \\
\end{array}$ & TUO & TU12-01 & RU01-01 & Rบ02-01 & RU09-01 \\
\hline $\begin{array}{l}\mathrm{La} \\
\mathrm{Ce} \\
\mathrm{Pr} \\
\mathrm{Nd} \\
\mathrm{Sm} \\
\mathrm{Eu} \\
\mathrm{Gd} \\
\mathrm{Tb} \\
\mathrm{Dy} \\
\mathrm{Ho} \\
\mathrm{Er} \\
\mathrm{Tm} \\
\mathrm{Yb} \\
\mathrm{Lu}\end{array}$ & $\begin{array}{r}4.0 \\
15.0 \\
2.8 \\
16.6 \\
5.0 \\
1.7 \\
4.9 \\
0.7 \\
3.8 \\
0.6 \\
1.3 \\
0.2 \\
0.8 \\
0.1\end{array}$ & $\begin{array}{r}4.1 \\
15.1 \\
2.8 \\
14.9 \\
4.2 \\
1.5 \\
4.3 \\
0.6 \\
3.2 \\
0.5 \\
1.1 \\
0.1 \\
0.7 \\
0.1\end{array}$ & $\begin{array}{r}7.9 \\
28.5 \\
5.3 \\
29.5 \\
8.4 \\
2.7 \\
8.1 \\
1.1 \\
5.8 \\
0.9 \\
1.9 \\
0.2 \\
1.3 \\
0.2\end{array}$ & $\begin{array}{r}3.2 \\
11.1 \\
2.0 \\
10.9 \\
3.1 \\
1.1 \\
3.0 \\
0.4 \\
2.4 \\
0.4 \\
0.8 \\
0.1 \\
0.6 \\
0.1\end{array}$ & $\begin{array}{r}7.5 \\
25.7 \\
4.7 \\
24.8 \\
6.8 \\
2.2 \\
6.5 \\
0.9 \\
5.1 \\
0.8 \\
1.8 \\
0.2 \\
1.3 \\
0.2\end{array}$ & $\begin{array}{l}2.1 \\
7.7 \\
1.4 \\
7.8 \\
2.3 \\
0.8 \\
2.4 \\
0.4 \\
2.1 \\
0.4 \\
0.8 \\
0.1 \\
0.6 \\
0.1\end{array}$ & $\begin{array}{r}3.1 \\
11.2 \\
2.1 \\
11.6 \\
3.4 \\
1.2 \\
3.6 \\
0.5 \\
3.0 \\
0.5 \\
1.1 \\
0.1 \\
0.8 \\
0.1\end{array}$ & \begin{tabular}{r|}
3.2 \\
11.8 \\
2.2 \\
12.1 \\
3.5 \\
1.2 \\
3.6 \\
0.5 \\
2.9 \\
0.5 \\
1.1 \\
0.1 \\
0.8 \\
0.1
\end{tabular} & $\begin{array}{r}2.6 \\
9.8 \\
1.9 \\
10.7 \\
3.3 \\
1.1 \\
3.5 \\
0.5 \\
2.9 \\
0.5 \\
1.2 \\
0.1 \\
0.9 \\
0.1\end{array}$ & $\begin{array}{r}2.9 \\
10.0 \\
1.8 \\
9.8 \\
2.7 \\
0.9 \\
2.9 \\
0.4 \\
2.4 \\
0.4 \\
0.9 \\
0.1 \\
0.7 \\
0.1\end{array}$ & $\begin{array}{r}6.0 \\
20.8 \\
3.6 \\
19.4 \\
5.3 \\
1.7 \\
5.3 \\
0.8 \\
4.6 \\
0.8 \\
1.8 \\
0.2 \\
1.4 \\
0.2\end{array}$ & $\begin{array}{r}5.3 \\
18.4 \\
3.2 \\
16.8 \\
4.4 \\
1.5 \\
4.4 \\
0.6 \\
3.3 \\
0.5 \\
1.1 \\
0.1 \\
0.8 \\
0.1\end{array}$ & $\begin{array}{l}2.8 \\
9.6 \\
1.7 \\
9.2 \\
2.6 \\
0.9 \\
2.7 \\
0.4 \\
2.3 \\
0.4 \\
0.9 \\
0.1 \\
0.7 \\
0.1\end{array}$ & $\begin{array}{l}1.9 \\
7.1 \\
1.3 \\
7.7 \\
2.5 \\
0.9 \\
2.7 \\
0.4 \\
2.5 \\
0.4 \\
1.0 \\
0.1 \\
0.7 \\
0.1\end{array}$ & $\begin{array}{l}2.1 \\
7.5 \\
1.4 \\
7.9 \\
2.5 \\
0.8 \\
2.6 \\
0.4 \\
2.3 \\
0.4 \\
0.9 \\
0.1 \\
0.7 \\
0.1\end{array}$ & $\begin{array}{l}1.9 \\
6.9 \\
1.2 \\
7.1 \\
2.3 \\
0.8 \\
2.5 \\
0.4 \\
2.3 \\
0.4 \\
0.9 \\
0.1 \\
0.7 \\
0.1\end{array}$ \\
\hline $\begin{array}{l}\mathrm{Rb} \\
\mathrm{Ba} \\
\mathrm{Th} \\
\mathrm{U} \\
\mathrm{Nb} \\
\mathrm{Ta} \\
\mathrm{Pb} \\
\mathrm{Sr} \\
\mathrm{Zr} \\
\mathrm{Hf} \\
\mathrm{Y}\end{array}$ & $\begin{array}{r}0.05 \\
1.3 \\
0.1 \\
0.01 \\
1.1 \\
0.1 \\
0.1 \\
93.5 \\
37.0 \\
1.9 \\
16.0 \\
\end{array}$ & $\begin{array}{c}0.1 \\
0.8 \\
0.1 \\
0.01 \\
0.6 \\
0.1 \\
0.1 \\
113 \\
25.7 \\
1.3 \\
14.8 \\
\end{array}$ & $\begin{array}{c}0.1 \\
1.6 \\
0.1 \\
0.01 \\
1.4 \\
0.2 \\
0.1 \\
133 \\
56.2 \\
2.7 \\
25.0 \\
\end{array}$ & $\begin{array}{c}0.1 \\
1.6 \\
0.1 \\
0.01 \\
0.4 \\
0.04 \\
0.1 \\
88.6 \\
14.0 \\
0.7 \\
10.6 \\
\end{array}$ & $\begin{array}{l}0.1 \\
1.4 \\
0.1 \\
0.02\end{array}$ & $\begin{array}{c}0.03 \\
0.3 \\
0.03 \\
\\
0.4 \\
0.04 \\
0.1 \\
54.4 \\
6.9 \\
0.4 \\
9.3 \\
\end{array}$ & $\begin{array}{c}0.1 \\
0.7 \\
0.05 \\
0.01 \\
0.7 \\
0.1 \\
0.1 \\
60.5 \\
11.4 \\
0.6 \\
13.3 \\
\end{array}$ & $\begin{array}{c}0.1 \\
1.1 \\
0.05 \\
0.01 \\
0.9 \\
0.1 \\
0.05 \\
63.5 \\
17.7 \\
0.9 \\
14.0 \\
\end{array}$ & $\begin{array}{c}0.1 \\
1.0 \\
0.04 \\
0.01 \\
0.8 \\
0.1 \\
0.04 \\
55.7 \\
22.2 \\
1.0 \\
14.0 \\
\end{array}$ & $\begin{array}{c}0.1 \\
0.2 \\
0.04 \\
0.01 \\
0.4 \\
0.05 \\
0.1 \\
60.6 \\
14.9 \\
0.8 \\
11.6 \\
\end{array}$ & $\begin{array}{c}0.2 \\
1.2 \\
0.1 \\
0.02 \\
1.0 \\
0.2 \\
0.1 \\
75.4 \\
41.3 \\
2.2 \\
21.4 \\
\end{array}$ & $\begin{array}{c}0.04 \\
0.5 \\
0.1 \\
0.01 \\
0.9 \\
0.1 \\
0.1 \\
105 \\
31.3 \\
1.7 \\
15.2 \\
\end{array}$ & $\begin{array}{c}0.1 \\
0.5 \\
0.1 \\
0.01 \\
0.5 \\
0.1 \\
0.1 \\
57.4 \\
7.3 \\
0.4 \\
10.6 \\
\end{array}$ & $\begin{array}{c}0.03 \\
1.6 \\
0.02 \\
0.7 \\
0.1 \\
0.02 \\
45.9 \\
16.0 \\
0.9 \\
10.7\end{array}$ & $\begin{array}{c}0.1 \\
0.4 \\
0.03 \\
\\
0.6 \\
0.1 \\
0.02 \\
49.8 \\
12.0 \\
0.7 \\
11.2 \\
\end{array}$ & $\begin{array}{c}0.4 \\
5.7 \\
0.1 \\
0.02 \\
1.3 \\
0.1 \\
0.04 \\
48.1 \\
15.4 \\
0.8 \\
10.7\end{array}$ \\
\hline
\end{tabular}

elemental concentrations cannot be explained by contamination of groundmass during sample preparation. Three possibilities are raised for the compositional difference between rim and core; (1) assimilation of country rocks after formation of the core, (2) fractionation of magma by crystallization, and (3) the change of cpx/ melt partition coefficients between the formation of core and that of rim. The first possibility is excluded by $\mathrm{Sr}$ and $\mathrm{Nd}$ isotope data as discussed above. The second possibility requires more than $50 \%$ crystallization between the formation of core and that of rim. However, maximum crystallization degree would not exceed $25 \%$ as suggested from $\mathrm{FeO} / \mathrm{MgO}$ ratios of core and rim. Hence, the second possibility alone fails to explain the difference in REE concentration between rim and core. The third possibility is based on the dependency of partitioning on pressure, temperature and compositional effects. Since partition coefficients of REEs are negatively correlated with temperature (Green and Pearson, 1985), REEs would tend to be more partitioned into cpx during the formation of the rim than of the core as cooling proceeds in the magma. However, it is uncertain whether partition coefficients of all REEs are equally sensitive to temperature changes as is suggested by the parallelism between the REE patterns of the rims and cores. Thus, the difference in the concentration of REEs is more likely to be due to a complex interplay involving magmatic fractionation and changes of partition coefficients between core and rim. This implies that petrogenetic discussion based on trace elements should be based on selecting appropriate pairs of elements with similar partition coefficients.

\section{Discussion}

\subsection{Constraints provided by Sr and Nd isotope data of cpx}

Cpx samples of the HIMU-OIBs show quite uniform values of ${ }^{87} \mathrm{Sr} /{ }^{86} \mathrm{Sr}(0.702738 \pm 0.000026(2 \sigma))$ compared with the whole rock samples which form a cloud of data in the $\mathrm{Sr}-\mathrm{Nd}$ diagram (Fig. 8). They have a small variation of $\varepsilon_{\mathrm{Nd}}$ between +3.3 and +5.5 . This trend is interpreted as being due to binary components mixing. One end-member of the higher $\varepsilon_{\mathrm{Nd}}$ side is the MORB source upper mantle material and/or oceanic lithosphere which could be incorporated into upwelling plumes. FOZO is another candidate, but it would be ruled out because of lack of primordial helium isotopic signature in HIMU samples 


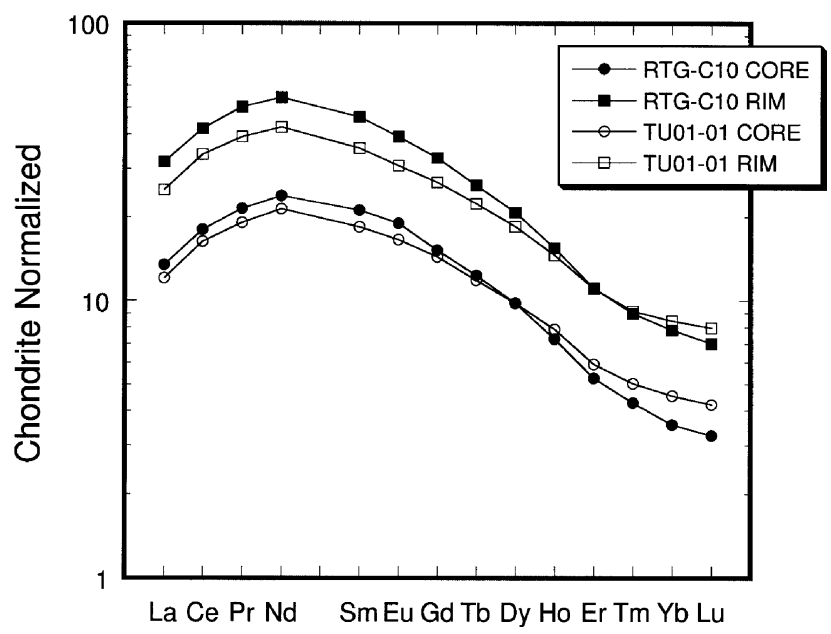

Fig. 7. Results of the rim-core test for cpx of RTG-C10 and TU01-01. Concentrations of REEs are normalized by those of chondrite (McDonough and Sun, 1995).

(Hanyu and Kaneoka, 1997). The other end-member of the lower $\varepsilon_{\mathrm{Nd}}$ side is the HIMU end-member component.

Saal et al. (1998) have recently reported internal heterogeneity of $\mathrm{Pb}$ isotope ratios among melt inclusions in phenocrysts from HIMU samples, even though the erupted lavas are isotopically homogeneous. Small variation of ${ }^{87} \mathrm{Sr} /{ }^{86} \mathrm{Sr}$ and $\varepsilon_{\mathrm{Nd}}$ observed in cpx samples does not contradict their findings, because existence of melt inclusions in phenocrysts may not contribute much to bulk analyses of $\mathrm{Sr}$ and $\mathrm{Nd}$ isotopes, as well as $\mathrm{Pb}$ isotopes. However, it may be noted that analyses of individual inclusions would reveal more extensive trend in the $\mathrm{Sr}-\mathrm{Nd}$ isotope diagram than those observed from bulk cpx samples.

$\varepsilon_{\mathrm{Nd}}$ values of HIMU samples weakly correlate with the ages of the islands (Fig. 2). The oldest Mangaia samples have $\varepsilon_{\mathrm{Nd}}$ values lower than those of the older Rurutu and Tubuai samples. Reported $\mathrm{Pb}$ isotope ratios also show a similar tendency with ${ }^{206} \mathrm{~Pb} /{ }^{204} \mathrm{~Pb},{ }^{207} \mathrm{~Pb} /{ }^{204} \mathrm{~Pb}$ and ${ }^{208} \mathrm{~Pb} /$ ${ }^{204} \mathrm{~Pb}$ of Mangaia samples being the highest among the three islands (Palacz and Saunders, 1986; Nakamura and Tatsumoto, 1988; Chauvel et al., 1992, Chauvel et al., 1997). These isotopic trends may suggest a progressive entrainment of MORB-like components into the HIMUmantle plumes from $18 \mathrm{Ma}$ (Mangaia) to $10 \mathrm{Ma}$ (Tubuai). However, the matter should be left open because the correlation between $\varepsilon_{\mathrm{Nd}}$ and ages of islands is not clear when previous data are considered.

The vertical linear trend of HIMU-OIBs in the $\mathrm{Sr}-\mathrm{Nd}$ diagram provides strong constraints in respect of the following points. (1) The HIMU end-member should be less than +3.3 which corresponds to the lowest $\varepsilon_{\mathrm{Nd}}$ of our cpx samples, and (2) HIMU-OIBs have the lowest ${ }^{87} \mathrm{Sr} /$ ${ }^{86} \mathrm{Sr}$ among OIBs and the value is similar to that of the MORB source. These constraints make it obvious that HIMU-OIBs are plotted apart from the mantle array in $\mathrm{Sr}$ Nd systematics.

The former constraint indicates that time-integrated $\mathrm{Sm} / \mathrm{Nd}$ of the HIMU source should be lower than that of

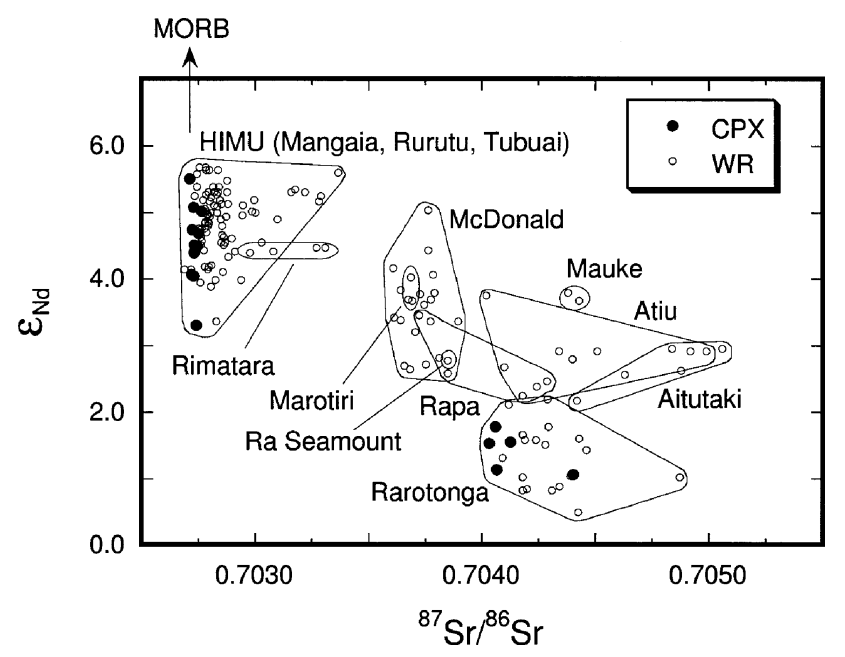

Fig. 8. Compilation of ${ }^{87} \mathrm{Sr} /{ }^{86} \mathrm{Sr}$ and $\varepsilon_{\mathrm{Nd}}$ data for the Cook-Austral Islands. The isotopic range of each island is shown by loops. Data sources are from Vidal et al. (1984), Palacz and Saunders (1986), Nakamura and Tatsumoto (1988), McDonough and Chauvel (1991), Chauvel et al. (1992), Hauri and Hart (1993), Hémond et al. (1994), Woodhead (1996), Chauvel et al. (1997) and this study.

the MORB source upper mantle. In this respect, it seems to be difficult to recognize the HIMU source as recycled ancient oceanic crust itself (Hofmann and White, 1982; Weaver, 1991; Chauvel et al., 1992; Hauri and Hart, 1993; Reisberg et al., 1993; Roy-Barman and Allègre, 1995; Hofmann, 1997; Kogiso et al., 1997) from the following reasons. Since the degree of depletion of the ancient MORB source (1-2 Ga) would be similar to that of the present MORB source (e.g., Sylvester et al., 1997), the $\mathrm{Sm} / \mathrm{Nd}$ ratio of the ancient MORB source would not be significantly different from that of the present MORB source. When oceanic crust (MORB) was formed at midocean ridges, decrease of $\mathrm{Sm} / \mathrm{Nd}$ ratio would not be sufficient to explain the present $\varepsilon_{\mathrm{Nd}}$ of the HIMU source unless it is generated by small degree of melting $(<5 \%)$. Hydrothermal alteration would not significantly modify concentration of REEs (Michard et al., 1983; Dostal and Dupuy, 1996), and dehydration processes would rather increase the $\mathrm{Sm} / \mathrm{Nd}$ ratio of subducted oceanic crust (Kogiso et al., 1997).

Two possible interpretations remain for the latter constraint. One interpretation is that time-integrated $\mathrm{Rb} /$ $\mathrm{Sr}$ of the HIMU source is lower than that of any other OIB sources and as low as that of the MORB source. Reduction of $\mathrm{Rb} / \mathrm{Sr}$ might be caused by dehydration processes during subduction of slabs. Although $\mathrm{Rb} / \mathrm{Sr}$ of the HIMU source may accidentally match with that of the MORB source, however, we prefer another interpretation that $\mathrm{Sr}$ is more depleted than $\mathrm{Nd}$ in the HIMU source by dehydration during subduction. If the HIMU source has lower $\mathrm{Sr} / \mathrm{Nd}$ than the MORB source, vertical trend of HIMU-OIBs can be explained by their mixing. In this case, Sr in the HIMUOIBs mostly derived from the MORB source end-member. For both possibilities, anyway, the reduction of $\mathrm{Rb} / \mathrm{Sr}$ or $\mathrm{Sr} / \mathrm{Nd}$ is required for the HIMU source. Dehydration processes will probably cause such reduction (e.g., Chauvel et al., 1995) because $\mathrm{Rb}$ is strongly partitioned to fluids 
(especially to $\mathrm{NaCl}$ fluids) than $\mathrm{Sr}$, and $\mathrm{Sr}$ is more soluble to fluids than REEs (Keppler, 1996).

Instead of recycled oceanic crust model as the HIMU origin, we may propose a model that the HIMU source was produced from recycled oceanic crust with sediments. Addition of sediments to the oceanic crust simply explains low $\varepsilon_{\mathrm{Nd}}$ signature of HIMU. However, one may say against the model that mixture of sediments and the oceanic crust would have elevated ${ }^{87} \mathrm{Sr} /{ }^{86} \mathrm{Sr}$, although HIMU samples show relatively low ${ }^{87} \mathrm{Sr} /{ }^{86} \mathrm{Sr}$. We may explain it as follows. Mixture of oceanic crust and sediments would certainly have elevated ${ }^{87} \mathrm{Sr} /{ }^{86} \mathrm{Sr}$. However, dehydration during subduction would reduce their $\mathrm{Sr} / \mathrm{Nd}$ and $\mathrm{Rb} / \mathrm{Sr}$ ratios. Low $\mathrm{Rb} / \mathrm{Sr}$ ratio causes less increase of ${ }^{87} \mathrm{Sr} /{ }^{86} \mathrm{Sr}$ after subduction. Then, recent mixing between the HIMU source and MORB source in the upwelling plumes forms vertical trend in the $\mathrm{Sr}-\mathrm{Nd}$ diagram because the HIMU source has reduced $\mathrm{Sr} / \mathrm{Nd}$ ratio.

Simple mixing calculation demonstrates that small contribution of ancient sediments to oceanic crust is enough to account for lower $\varepsilon_{\mathrm{Nd}}$ of the present HIMU source than the MORB source. Difference of $7 \varepsilon_{\mathrm{Nd}}$-units between them requires that ${ }^{147} \mathrm{Sm} /{ }^{144} \mathrm{Nd}$ of the HIMU source should be 0.027 lower than that of the MORB source assuming that the HIMU source had formed 2 Gy ago. Since ${ }^{147} \mathrm{Sm} /{ }^{144} \mathrm{Nd}$ and $\mathrm{Nd}$ content of the ancient MORB and typical sediments are 0.2 and 10 (Chauvel et al., 1992), and 0.12 and >30 (Ben Othman et al., 1989), respectively, contribution of sediments to oceanic crust should be less than $10 \%$. Accordingly, involved sediments in the HIMU source is small in volume. Such a contribution

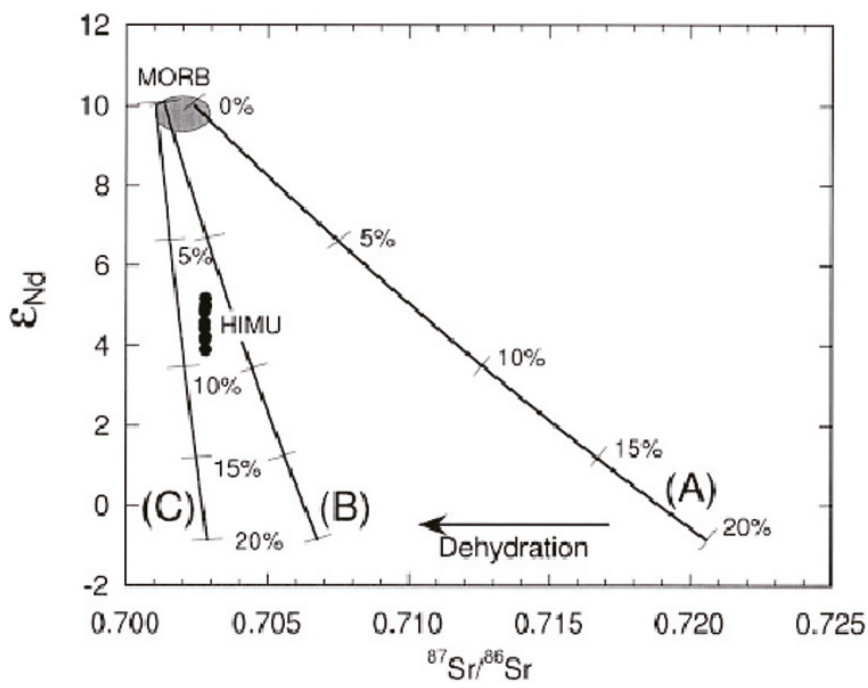

Fig. 9. The present $\mathrm{Sr}$ and $\mathrm{Nd}$ isotope ratios of the HIMU source. It is assumed that the HIMU source was produced by mixing of ancient MORB and sediment 2 Gy ago (Line (A)). The numbers attached to ticks indicate mixing ratio of sediments. Reduction of $\mathrm{Rb} / \mathrm{Sr}$ by dehydration after mixing shifts mixing line leftward in the figure. Line (B) and (C) shows the cases that reduction factors are 0.3 and 0.1 , respectively. End-member components are; $\mathrm{MORB},{ }^{87} \mathrm{Rb} /{ }^{86} \mathrm{Sr}=$ $0.054, \mathrm{Sr}=100 \mathrm{ppm},{ }^{147} \mathrm{Sm} /{ }^{144} \mathrm{Nd}=0.22, \mathrm{Nd}=0.2 \mathrm{ppm}$; sediment, ${ }^{87} \mathrm{Rb} /{ }^{86} \mathrm{Sr}=2, \mathrm{Sr}=200 \mathrm{ppm},{ }^{147} \mathrm{Sm} /{ }^{144} \mathrm{Nd}=0.12, \mathrm{Nd}=30 \mathrm{ppm}($ Ben Othman et al., 1989; Chauvel et al., 1992). ${ }^{87} \mathrm{Sr} /{ }^{86} \mathrm{Sr}$ and ${ }^{143} \mathrm{Nd} /{ }^{144} \mathrm{Nd}$ of the MORB source 2 Gy ago are 0.70089 and 0.51029 , respectively. would not be detected by trace elemental pattern, but should be regarded as important in the issue of $\mathrm{Sr}$ and $\mathrm{Nd}$ isotopes. Figure 9 schematically shows the present $\mathrm{Sr}$ and $\mathrm{Nd}$ isotope ratios of the HIMU source assuming that it was produced by mixing of ancient MORB and sediment $2 \mathrm{~Gy}$ ago. As mixing of sediments with oceanic crust causes increase of $\mathrm{Rb} / \mathrm{Sr}$ as well as reduction of $\mathrm{Sm} / \mathrm{Nd}$, reduction of $\mathrm{Rb} / \mathrm{Sr}$ and/or $\mathrm{Sr} / \mathrm{Nd}$ by dehydration is required to explain ${ }^{87} \mathrm{Sr} /{ }^{86} \mathrm{Sr}$ of HIMU as low as that of the present depleted mantle.

\subsection{Correlation between incompatible elements and $\varepsilon_{\mathrm{Nd}}$}

In the discussion of incompatible elements, it is important to choose appropriate pairs of elements because their concentrations have been modified by complex processes of fractionation as revealed by comparison of rim and core analyses of cpx. Element pairs that can be discussed without considering crystallization effects should have similar partitioning coefficients for cpx/melt and olivine/ melt. Further, element pairs with similar incompatibility between cpx/melt and garnet/melt are suitable because garnet and cpx are the significant residual phases and the major reservoirs of incompatible trace elements during the melting processes of magma generation. In practice, olivine/melt partitioning would not be significant because partition coefficients for olivine are much smaller than those of cpx/melt and garnet/melt for most incompatible elements.

Considering cpx/melt and garnet/melt partitioning (Fig. 6), one of the recommended element pairs is $\mathrm{Pb}-\mathrm{Ta}$. The $\mathrm{Pb} / \mathrm{Ta}$ ratio actually correlates with $\varepsilon_{\mathrm{Nd}}$ for HIMU samples (Fig. 10) although most other element ratios do not correlate with $\varepsilon_{\mathrm{Nd}}$. This trend is also explained by mixing of the MORB source with $\varepsilon_{\mathrm{Nd}}=+10$ and the HIMU source with $\varepsilon_{\mathrm{Nd}}<+3.3$. The $\mathrm{Pb} / \mathrm{Ta}$ ratio of the HIMU source is lower than that of the MORB source, suggesting

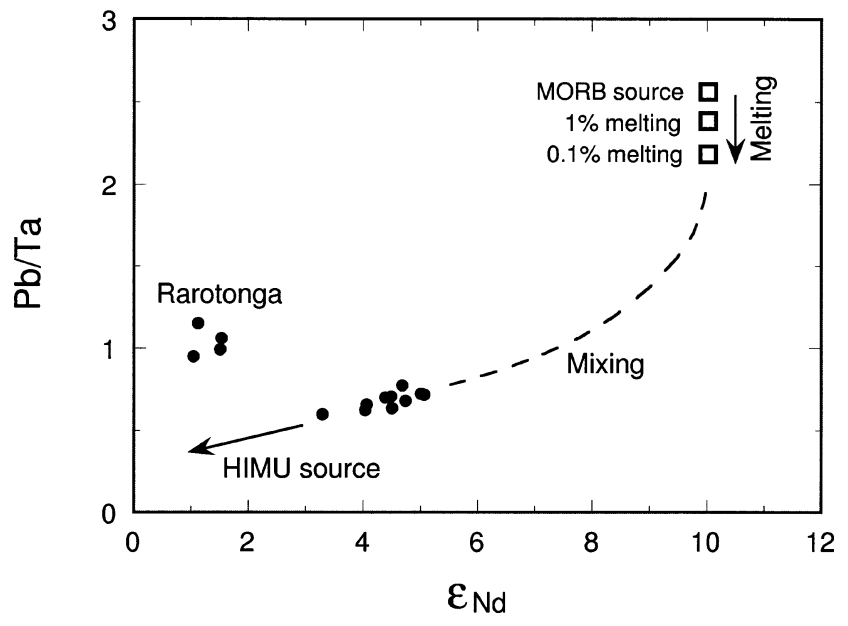

Fig. 10. $\varepsilon_{\mathrm{Nd}}-\mathrm{Pb} / \mathrm{Ta}$ diagram for HIMU and EM samples. Compositions of partial melt from the MORB source are also shown. $\varepsilon_{\mathrm{Nd}}$ of the MORB source is assumed to be +10 . $\mathrm{Pb} / \mathrm{Ta}$ of the N-MORB is assumed to be 2.55 (Hofmann, 1988). $\mathrm{Pb} / \mathrm{Ta}$ of the MORB source and its melt with various degree of melting are calculated using partition coefficients of spinel peridotite (McKenzie and O'Nions, 1991) assuming that N-MORB was formed by $10 \%$ melting. 


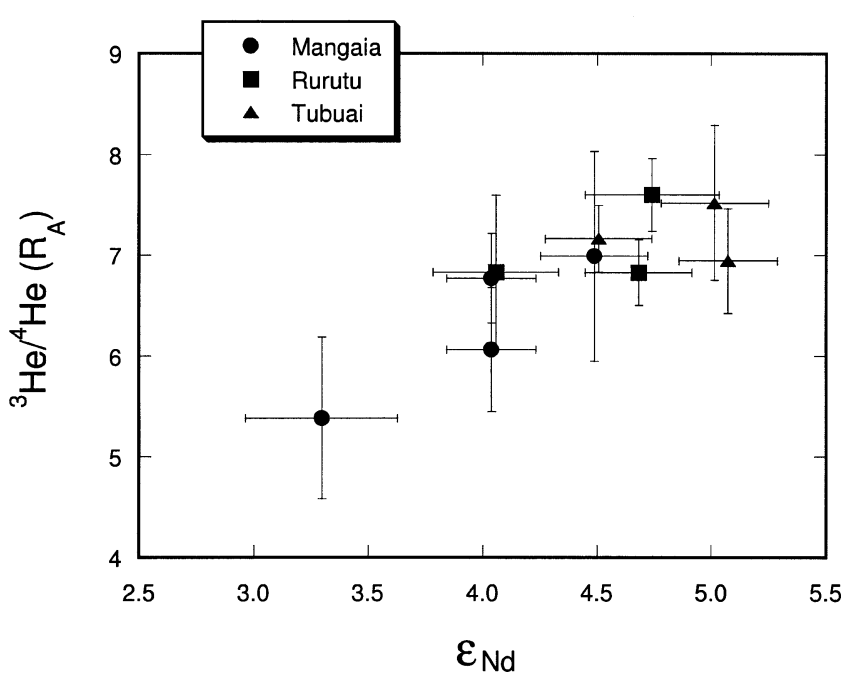

Fig. 11. Correlation between $\varepsilon_{\mathrm{Nd}}$ and ${ }^{3} \mathrm{He} /{ }^{4} \mathrm{He} .{ }^{3} \mathrm{He} /{ }^{4} \mathrm{He}$ is normalized to the atmospheric value. Data from Hanyu and Kaneoka (1997) and this study.

that $\mathrm{Pb}$ is more depleted than HFSE in the HIMU source. Such a scenario is also compatible with the model that the HIMU source consists of dehydrated ancient subducted material. Samples from Rarotonga show rather higher $\mathrm{Pb} /$ Ta. Since these data do not plot on the HIMU sourceMORB source mixing trend, another component is required for the Rarotonga-OIBs as also suggested from $\mathrm{Sr}, \mathrm{Nd}$ and $\mathrm{Pb}$ isotopes.

We may note, in passing, a possible correlation between $\varepsilon_{\mathrm{Nd}}$ and ${ }^{3} \mathrm{He} /{ }^{4} \mathrm{He}$ in the HIMU samples (Fig. 11). Although this correlation is not very clear, the sample with the lowest $\varepsilon_{\mathrm{Nd}}(\mathrm{MGA}-\mathrm{C} 29)$ shows the lowest ${ }^{3} \mathrm{He} /{ }^{4} \mathrm{He}\left(5.4 \mathrm{R}_{\mathrm{A}}\right.$; Hanyu and Kaneoka, 1997). This may support the idea of binary mixing between the MORB source and HIMU source. The HIMU end-member is characterized by low $\varepsilon_{\mathrm{Nd}}$ and low ${ }^{3} \mathrm{He} /{ }^{4} \mathrm{He}$, which is consistent with the idea that the HIMU source is derived from subducted material whose $\mathrm{He} / \mathrm{U}$ ratio was reduced by degassing at the Earth's surface (Hanyu and Kaneoka, 1997).

\section{Summary}

The origin of the HIMU and EM sources has been examined on the basis of analyses of $\mathrm{Sr}$ and $\mathrm{Nd}$ isotopes as well as trace elements for the Polynesian OIBs. Analyses of cpx samples enables the complete recovery of the primary isotopic character of the magma. HIMU samples have uniform ${ }^{87} \mathrm{Sr} /{ }^{86} \mathrm{Sr}$ ratios $(\sim 0.70274)$ similar to those of MORB. Small variation of $\varepsilon_{\mathrm{Nd}}(+3.3 \sim+5.5)$ among HIMU samples is explained by mixing of the HIMU endmember and the MORB source. $\varepsilon_{\mathrm{Nd}}$ of the HIMU endmember is constrained to be less than +3.3 . The vertical linear trend of the HIMU-OIBs in the $\mathrm{Sr}-\mathrm{Nd}$ isotope diagram indicates that time-integrated $\mathrm{Rb} / \mathrm{Sr}$ of the HIMU source should be similar to that of the MORB source, or $\mathrm{Sr} / \mathrm{Nd}$ of the HIMU source should be much less than that of the MORB source. This is consistent with the model that the HIMU source was derived from dehydrated subducted materials as previously suggested by $\mathrm{Pb}$ isotopic studies. Correlation between $\varepsilon_{\mathrm{Nd}}$ and $\mathrm{Pb} / \mathrm{Ta}$ also supports this model. However, a new suggestion derived from the present study is that the HIMU source cannot be formed by only recycled oceanic crust and may include subducted sediments as suggested by its low $\varepsilon_{\mathrm{Nd}}$.

Acknowledgments. We thank T. Kogiso and H. G. Barsczus for donating samples of Mangaia and Rarotonga Islands, and R. Maury for his help during sampling in Rurutu and Tubuai Islands. Discussion with I. Kaneoka is gratefully acknowledged. Reviews by C. Chauvel and T. Kogiso improved the quality of the manuscript. We are grateful to K. Aoki for his suggestions on sample description and preparation. A. Makishima, T. Shibata, M. Yoshikawa, T. Moriguti, Y. Iizuka, T. Nakano, K. Kobayashi and N. Akiyoshi are acknowledged for analytical help. This program was undertaken in a collaboration program at Institute for Study of the Earth's Interior, Okayama University at Misasa.

\section{References}

Allègre, C. J., O. Brévart, B. Dupré, and J. F. Minster, Isotopic and chemical effects produced in a continuously differentiating convecting earth mantle, Philos. Trans. R. Soc. Lond., A297, 447-477, 1980.

Barsczus, H. G., G. Guille, R. Maury, C. Chauvel, and H. Guillou, Two magmatic sources at Rurutu Island (Austral Islands, French Polynesia) and the Austral "Hotline", EOS, 75, 323, 1994.

Ben Othman, D., W. M. White, and J. Patchett, The geochemistry of marine sediments, island arc magma genesis, and crust-mantle recycling, Earth Planet. Sci. Lett., 94, 1-21, 1989.

Chauvel, C., A. W. Hofmann, and P. Vidal, HIMU-EM: The French Polynesian connection, Earth Planet. Sci. Lett., 110, 99-119, 1992.

Chauvel, C., S. L. Goldstein, and A. H. Hofmann, Hydration and dehydration of oceanic crust controls $\mathrm{Pb}$ evolution in the mantle, Chem. Geol., 126, 65-75, 1995.

Chauvel, C., W. McDonough, G. Guille, R. Maury, and R. Duncan, Contrasting old and young volcanism in Rurutu Island, Austral chain, Chem. Geol., 139, 125-143, 1997.

Dostal, J., C. Dupuy, and P. Dudoignon, Distribution of boron, lithium and beryllium in oceanic island basalts from French Polynesia: implications for the $\mathrm{B} / \mathrm{Be}$ and $\mathrm{Li} / \mathrm{Be}$ ratios as tracers of subducted components, Mineral. Magazine, 60, 563-580, 1996.

Duncan, R. A. and I. McDougall, Linear volcanism in French Polynesia, J. Volcanol. Geotherm. Res., 1, 197-227, 1976.

Dziewonski, A. M., Mapping the lower mantle: Determination of lateral heterogeneity in $\mathrm{P}$ velocity up to degree and order $6, J$. Geophys. Res., 89, 5929-5952, 1984.

Eiler, J. M., K. A. Farley, J. W. Valley, E. Hauri, H. Craig, S. R. Hart, and E. M. Stolper, Oxygen isotope variations in ocean island basalt phenocrysts, Geochim. Cosmochim. Acta, 61, 2281-2293, 1997.

Fukao, Y., Seismic tomogram of the Earth's mantle: geodynamic implications, Nature, 258, 625-630, 1992.

Graham, D. W., S. E. Humphris, W. J. Jenkins, and M. D. Kurz, Helium isotope geochemistry of some volcanic rocks from Saint Helena, Earth Planet. Sci. Lett., 110, 121-131, 1992.

Green, T. H., Experimental studies of trace-element partitioning applicable to igneous petrogenesis-Sedona 16 years later, Chem. Geol., 117, 1-36, 1994.

Green, T. H. and N. J. Pearson, Rare earth element partitioning between clinopyroxene and silicate liquid at moderate to high pressure, Contrib. Mineral. Petrol., 91, 24-36, 1985.

Halliday, A. N., D.-C. Lee, S. Tommasini, G. R. Davies, C. R. Paslick, J. G. Fitton, and D. E. James, Incompatible trace elements in OIB and MORB and source enrichment in the sub-oceanic mantle, Earth Planet. Sci. Lett., 133, 379-395, 1995.

Hanyu, T. and I. Kaneoka, The uniform and low ${ }^{3} \mathrm{He} /{ }^{4} \mathrm{He}$ ratios of HIMU basalts as evidence for their origin as recycled materials, Nature, 390, 273-276, 1997.

Hanyu, T., I. Kaneoka, and K. Nagao, Noble gas study of HIMU and EM ocean island basalts in the Polynesian region, Geochim. Cosmochim. Acta, 63, 1181-1201, 1999. 
Hauri, E. H. and S. R. Hart, Re-Os isotope systematics of HIMU and EMII oceanic island basalts from the south Pacific Ocean, Earth Planet. Sci. Lett., 114, 353-371, 1993.

Hémond, C., C. W. Devey, and C. Chauvel, Source compositions and melting processes in the Society and Austral plumes (South Pacific Ocean): Element and isotope ( $\mathrm{Sr}, \mathrm{Nd}, \mathrm{Pb}, \mathrm{Th})$ geochemistry, Chem. Geol., 115, 7-45, 1994.

Hofmann, A. W., Chemical differentiation of the Earth: the relationship between mantle, continental crust, and oceanic crust, Earth Planet. Sci. Lett., 90, 297-314, 1988.

Hofmann, A. W., Mantle geochemistry: the message from oceanic volcanism, Nature, 385, 219-229, 1997

Hofmann, A. W. and W. M. White, Mantle plumes from ancient oceanic crust, Earth Planet. Sci. Lett., 57, 421-436, 1982.

Keppler, H., Constraints from partitioning experiments on the composition of subduction-zone fluids, Nature, 380, 237-240, 1996

Kogiso, T., Y. Tatsumi, G. Shimoda, and H. G. Barsczus, High $\mu$ (HIMU) ocean basalts in southern Polynesia: New evidence for whole mantle scale recycling of subducted oceanic crust, J. Geophys. Res., 102, 8085-8103, 1997.

Makishima, A. and E. Nakamura, Suppression of matrix effects in ICPMS by high power operation of ICP: Application to precise determination of $\mathrm{Rb}, \mathrm{Sr}, \mathrm{Y}, \mathrm{Cs}, \mathrm{Ba}, \mathrm{REE}, \mathrm{Pb}$, Th and $\mathrm{U}$ at $\mathrm{ng} \mathrm{g}^{-1}$ levels in milligram silicate samples, Geostand. News Lett., 21, 307-319, 1997.

Makishima, A., E. Nakamura, and T. Nakano, Determination of zirconium, niobium, hafnium and tantalum at $\mathrm{ng} \mathrm{g}^{-1}$ levels in geological materials by direct nebulization of back-extracted sample HF solutions into FI-ICPMS, Geostands Newslett., 23, 7-20, 1999.

McDonough, W. F. and C. Chauvel, Sample contamination explains the $\mathrm{Pb}$ isotopic composition of some Rurutu island and Sasha seamount basalts, Earth Planet. Sci. Lett., 105, 397-404, 1991.

McDonough, W. F. and S.-S. Sun, The composition of the Earth, Chem. Geol., 120, 223-253, 1995.

McKenzie, D. and R. K. O'Nions, Mantle reservoirs and ocean island basalts, Nature, 301, 229-231, 1983.

McKenzie, D. and R. K. O'Nions, Partial melt distributions from inversion of rare earth element concentrations, J. Petrol., 32, 10211091, 1991.

McNutt, M. K. and A. V. Judge, The superswell and mantle dynamics beneath the South Pacific, Science, 248, 969-975, 1990.

McNutt, M. K., D. W. Caress, J. Reynolds, K. A. Jordahl, and R. A. Duncan, Failure of plume theory to explain midplate volcanism in the southern Austral islands, Nature, 389, 479-482, 1997.

Michard, A., F. Albarède, G. Michard, J. F. Minster, and J. L. Charlou, Rare-earth elements and uranium in high-temperature solutions from East Pacific Rise hydrothermal vent field $\left(13^{\circ} \mathrm{N}\right)$, Nature, 303, 795 797, 1983.

Nakamura, Y. and M. Tatsumoto, $\mathrm{Pb}, \mathrm{Nd}$, and $\mathrm{Sr}$ isotopic evidence for a multicomponent source for rocks of Cook-Austral Islands and heterogeneities of mantle plumes, Geochim. Cosmochim. Acta, 52, 2909-2924, 1988.

Palacz, Z. A. and D. Saunders, Coupled trace element and isotope enrichment in the Cook-Austral-Samoa islands, southwest Pacific, Earth Planet. Sci. Lett., 79, 270-280, 1986.

Reisberg, L., A. Zindler, F. Marcantonio, W. White, D. Wyman, and B. Weaver, Os isotope systematics in ocean island basalts, Earth Planet. Sci. Lett., 120, 149-167, 1993.

Roy-Barman, M. and C. J. Allègre, ${ }^{187} \mathrm{Os} /{ }^{186} \mathrm{Os}$ in oceanic island basalts: tracing oceanic crust recycling in the mantle, Earth Planet. Sci. Lett., 129, 145-161, 1995.

Saal, A. E., S. R. Hart, N. Shimizu, E. H. Hauri, and G. D. Layne, Pb isotopic variability in melt inclusions from oceanic island basalts, Polynesia, Science, 282, 1481-1484, 1998.

Shibata, T. and E. Nakamura, Across-arc variations of isotope and trace element compositions from Quaternary basaltic volcanic rocks in northeastern Japan: Implications for interaction between subducted oceanic slab and mantle wedge, J. Geophys. Res., 102, 8051-8064, 1997.

Sun, S.-S. and W. F. McDonough, Chemical and isotopic systematics of oceanic basalts: implications for mantle composition and processes, in Magmatism in the Ocean Basins, edited by A. D. Saunders, M. J. Norry, pp. 313-345, Geol. Soc. Spec. Pub. No. 42, 1989.

Sylvester, P. J., I. H. Campbell, and D. A. Bowyer, Niobium/uranium evidence for early formation of the continental crust, Science, 275, 521-523, 1997.

Turner, D. L. and R. D. Jarrard, K-Ar dating of the Cook-Austral island chain: a test of the hot-spot hypothesis, J. Volcanol. Geotherm. Res., 12, 187-220, 1982.

Vidal, P. and L. Dosso, Core formation: Catastrophic or continuous? $\mathrm{Sr}$ and $\mathrm{Pb}$ isotope constraints, Geophys. Res. Lett., 5, 169-172, 1978.

Vidal, P., C. Chauvel, and R. Brousse, Large mantle heterogeneity beneath French Polynesia, Nature, 307, 536-538, 1984.

Vollmer, R., Earth degassing, mantle metasomatism, and isotopic evolution of the mantle, Geology, 11, 452-454, 1983.

Weaver, B. L., The origin of ocean island basalt end-member compositions: trace element and isotopic constraints, Earth Planet. Sci. Lett., 104, 381-397, 1991.

Woodhead, J. D., Extreme HIMU in an oceanic setting: the geochemistry of Mangaia Island (Polynesia), and temporal evolution of the CookAustral hotspot, J. Volcanol. Geotherm. Res., 72, 1-19, 1996.

Yoshikawa, M. and E. Nakamura, Precise isotope determination of trace amounts of Sr in magnesium-rich samples, J. Min. Petr. Econ. Geol., 88, 548-561, 1993.

Zindler, A. and S. Hart, Chemical geodynamics, Ann. Rev. Earth Planet. Sci., 14, 493-571, 1986.

T. Hanyu (e-mail: hant@geo.vu.nl) and E. Nakamura (e-mail: eizonak@misasa.okayama-u.ac.jp) 